\title{
PET Imaging of VPAC1 Expression in Experimental and Spontaneous Prostate Cancer
}

\author{
Kaijun Zhang ${ }^{1}$, Mohan R. Aruva ${ }^{1}$, Nylla Shanthly ${ }^{1}$, Christopher A. Cardi ${ }^{1}$, Satish Rattan ${ }^{2}$, Chirag Patel ${ }^{2}$, \\ Christopher $\mathrm{Kim}^{1}$, Peter A. $\mathrm{McCue}^{3}$, Eric Wickstrom ${ }^{4,5}$, and Mathew L. Thakur ${ }^{1,5}$ \\ ${ }^{I}$ Department of Radiology, Thomas Jefferson University, Philadelphia, Pennsylvania; ${ }^{2}$ Department of Medicine, Thomas Jefferson \\ University, Philadelphia, Pennsylvania; ${ }^{3}$ Department of Pathology Anatomy and Cell Biology, Thomas Jefferson University, \\ Philadelphia, Pennsylvania; ${ }^{4}$ Department of Biochemistry and Molecular Pharmacology, Thomas Jefferson University, Philadelphia, \\ Pennsylvania; and ${ }^{5}$ Kimmel Cancer Center, Thomas Jefferson University, Philadelphia, Pennsylvania
}

Among U.S. men, prostate cancer (PC) accounts for $29 \%$ of all newly diagnosed cancers. A reliable scintigraphic agent to image $\mathrm{PC}$ and its metastatic or recurrent lesions and to determine the effectiveness of its treatment will contribute to the management of this disease. All PC overexpresses VPAC1 receptors. This investigation evaluated a probe specific for a ${ }^{64} \mathrm{Cu}$-labeled receptor for PET imaging of experimental human PC in athymic nude mice and spontaneously grown PC in transgenic mice. Methods: The probe, TP3939, was synthesized, purified, and labeled with

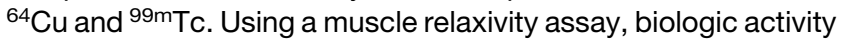
was assessed and inhibitory concentrations of $50 \%$ calculated. Receptor affinity (Kd) for human PC3 cells was determined using 99mTc-TP3939 and ${ }^{64} \mathrm{CuCl}_{2}$. Blood clearance and in vivo stability were studied. After intravenous administration of either ${ }^{64} \mathrm{Cu}-$ TP3939 or ${ }^{64} \mathrm{CuCl}_{2}$ in PC3 xenografts and in transgenic mice, $\mathrm{PET} / \mathrm{CT}$ images were acquired. Prostate histology served as the gold standard. Organ distribution studies (percentage injected dose per gram [\%ID/g]) in normal prostate were performed. The ratios of tumor to muscle, tumor to blood, normal prostate to muscle, and tumor to normal prostate were determined. Results: Chemical and radiochemical purities of TP3939 were $96.8 \%$ and $98 \% \pm 2 \%$, respectively. Inhibitory concentrations of $50 \%$ and affinity constants were $4.4 \times 10^{-8} \mathrm{M}$ and $0.77 \times 10^{-9} \mathrm{M}$, respectively, for TP3939 and $9.1 \times 10^{-8} \mathrm{M}$ and $15 \times 10^{-9} \mathrm{M}$, respectively, for vasoactive intestinal peptide 28. Binding of ${ }^{64} \mathrm{CuCl}_{2}$ to $\mathrm{PC} 3$ was nonspecific. Blood clearance was rapid. In vivo transchelation of ${ }^{64} \mathrm{Cu}$-TP3939 to plasma proteins was less than $15 \% .{ }^{64} \mathrm{Cu}$-TP3939 uptake in PC was $7.48 \pm$ $3.63 \% \mathrm{ID} / \mathrm{g}$ at $4 \mathrm{~h}$ and $5.78 \pm 0.66 \% \mathrm{ID} / \mathrm{g}$ at $24 \mathrm{~h}$ after injection and was significantly $(P<0.05)$ greater than with ${ }^{64} \mathrm{CuCl}_{2}(4.79 \pm$ $0.34 \% \mathrm{ID} / \mathrm{g}$ and $4.03 \pm 0.83 \% \mathrm{ID} / \mathrm{g}$ at 4 and $24 \mathrm{~h}$, respectively). The ratios of $\mathrm{PC}$ to normal prostate at 4 and $24 \mathrm{~h}$ were 4 and 2.7, respectively. ${ }^{64} \mathrm{Cu}$-TP3939 distinctly imaged histologic grade IV prostate intraepithelial neoplasia in transgenic mice, but ${ }^{18} \mathrm{~F}-\mathrm{FDG}$ and CT did not. Conclusion: Data indicate that TP3939, with its uncompromised biologic activity, delineated xenografts and cases of occult PC that were not detectable with ${ }^{18} \mathrm{~F}-\mathrm{FDG} .{ }^{64} \mathrm{Cu}-\mathrm{TP} 3939$ is a promising probe for PET imaging of PC. It may also be useful for

Received May 21, 2007; revision accepted Sep. 29, 2007.

For correspondence or reprints contact: Mathew Thakur, PhD, Thomas Jefferson University, 1020 Locust St., 359 JAH, Philadelphia, PA 19107. Email: Mathew.Thakur@jefferson.edu

COPYRIGHT @ 2008 by the Society of Nuclear Medicine, Inc. localizing recurrent lesions and for determining the effectiveness of its treatment.

Key Words: ${ }^{64} \mathrm{Cu}-\mathrm{PET}$ imaging; prostate cancer; VPAC1 receptors

J Nucl Med 2008; 49:112-121

DOI: 10.2967/jnumed.107.043703

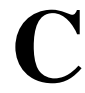

ancers of the prostate, lung, colon, and rectum account for $54 \%$ of all newly diagnosed cancers in U.S. men. The most common and lethal among them is prostate cancer (PC), accounting for about $29 \%$. The 2007 cancer data estimated 218,890 new cases and 27,050 deaths due to PC (1). The incidence of PC increases with age and is linked with genetic, hormonal, and environmental factors (2).

The primary screening methods for $\mathrm{PC}$ are prostate-specific antigen measurement and digital rectal examination (3). However, the reported sensitivity for digital rectal examination is only $55 \%-68 \%$ (4). For prostate-specific antigen, the specificity is limited because men with benign disease such as prostatic hypertrophy and prostatitis present with elevated levels of the antigen. Its positive predictive value in asymptomatic men has been reported to be only $28 \%-35 \%(4,5)$. This predictive value is marginally increased to $49 \%$ if prostate-specific antigen estimation is combined with the results of digital rectal examination (6). For more specific information in patients with abnormal digital rectal examination or prostate-specific antigen findings, transrectal ultrasound is performed. However, this too misses up to $40 \%$ of isoechoic lesions (7-9). X-ray CT lacks sufficient soft-tissue contrast to detect PC lesions (7). MRI suffers from limited application in detecting primary PC, although it provides high-resolution images to delineate prostate anatomy $(7,8,10)$.

In recent years, PET has emerged as a sensitive modality for imaging oncologic lesions. For PET imaging of PC, such metabolic and biochemical agents as ${ }^{18} \mathrm{~F}-\mathrm{FDG},{ }^{11} \mathrm{C}$-acetate, ${ }^{18} \mathrm{~F}$-acetate, ${ }^{11} \mathrm{C}$-methionine, ${ }^{11} \mathrm{C}$-choline, ${ }^{18} \mathrm{~F}$-choline, and $16 \beta-{ }^{18} \mathrm{~F}-5 \alpha$-dihydrotestosterone have been investigated $(11,12)$. However, all have met with serious limitations. For 
example, uptake of ${ }^{18} \mathrm{~F}-\mathrm{FDG}$, which is dependent on Glut-1 binding sites and the metabolic rate of tumor cells (13), is inhibited because PC has few Glut-1 binding sites and a slow metabolic rate. In addition, the adjacent bladder activity inhibits visualization of malignant lesions in the prostate gland. The 20-min half-life of ${ }^{11} \mathrm{C}$ limits application of all ${ }^{11} \mathrm{C}$ probes to locations where ${ }^{11} \mathrm{C}$ is produced in-house. ${ }^{18} \mathrm{~F}$-Flourine-labeled acetate, choline, and $16 \beta-{ }^{18} \mathrm{~F}-5 \alpha-$ dihydrotestosterone have had limited success $(11,14)$. Capromab pendetide (ProstaScint; Cytogen Corp.), a prostatespecific monoclonal antibody, has high blood-pool activity and nonspecific binding, which reduces its PC detection efficacy (11).

Recently, ionic ${ }^{64} \mathrm{CuCl}_{2}$ has been shown to be taken up by PC (15). The uptake was postulated to be facilitated by human copper transport 1 gene. Our data presented here indicate this uptake is nonspecific and dependent on cell line. These limitations have compelled investigators to search for better molecular probes to detect PC, to image its metastases, and to determine the effectiveness of its therapeutic interventions.

Vasoactive intestinal peptide (VIP) and pituitary adenylate cyclase-activating peptide receptors VPAC1, VPAC2, and PAC1 are overexpressed in 100\% of human PC (16-22). The 2 peptides, VIP and pituitary adenylate cyclase-activating peptide, have high affinity for these receptors $(23,24)$ and are excellent probes for targeting VPAC1 receptors. VIP, a 28-amino-acid hydrophobic peptide isolated from porcine intestine (25), has 3 lysine residues (at positions 15, 20, and 21), 2 tyrosine residues (at 10 and 22), 2 arginine residues (at 12 and 14), an essential histidine residue at its $\mathrm{N}$ terminus, and an (Asn) amidated $\mathrm{C}$ terminus. With the hypothesis that $\mathrm{VIP}_{28}$ labeled with the positron-emitting radionuclide ${ }^{64} \mathrm{Cu}$ could specifically target VPAC1 receptors for PET visualization of PC, we derivatized and synthesized a VIP analogue, TP3939. This analog, with $\mathrm{Lys}^{12}, \mathrm{Nle}^{17}\left(3-\mathrm{OH}_{3}, 4-\mathrm{OH}\right)$ $\mathrm{Phe}^{22}, \mathrm{Val}^{26}$, and $\mathrm{Thr}^{28}$, instead of VIP $\left(\mathrm{Arg}^{12}{ }^{12} \mathrm{Met}^{17}\right.$, $\mathrm{Tyr}^{22}, \mathrm{Ile}^{26}$, and $\mathrm{Asn}^{28}-\mathrm{NH}_{2}$ ), was chosen because it is more potent and biologically stable than $\operatorname{VIP}_{28}(26) .{ }^{64} \mathrm{Cu}$, with a half-life of $12.7 \mathrm{~h}\left(\beta^{+}=655 \mathrm{keV}[17.4 \%] ; \beta^{-}=573 \mathrm{keV}\right.$ $[30 \%]$ ), is commercially available, has an abundantly known chemistry, provides quantitative yields, and permits the use of its labeled compounds without further purification.

The purpose of this investigation was to evaluate ${ }^{64} \mathrm{Cu}-$ labeled TP3939, ascertain its biologic activity and receptor specificity, determine blood clearance, and perform tissue distribution and PET imaging of human PC xenografts in athymic nude mice and spontaneous PC in TRAMP (transgenic adenocarcinoma of mouse prostate) mice. ${ }^{18} \mathrm{FDG}$ and ${ }^{64} \mathrm{CuCl}_{2}$ served as controls.

\section{MATERIALS AND METHODS}

\section{Synthesis of TP3939}

TP3939 was synthesized by the American Peptide Co. TP3939 was synthesized to harbor a carboxy terminus lysine residue separated from VIP-asparagine by a spacer, $\gamma$-aminobutyric acid.
Diamine dithiol $\left(\mathrm{N}_{2} \mathrm{~S}_{2}\right)$ was used as the chelating agent. The peptide was synthesized on preloaded polyethylene glycol resin using standard 9-fluorenylmethyloxycarbonyl, 1,3-diisopropyl carbodiimide, and $N$-hydroxybenzotriazole chemistry. The 9-fluorenylmethyloxycarbonyl deprotection agent piperidine $20 \%$ in $N, N$-dimethyl formamide was also used. The crude peptide was precipitated from cold ether and collected by filtration. Purification was performed using reverse-phase high-performance liquid chromatography (HPLC) and triethylammonium phosphate and acetic acid buffer on a Waters C18 HPLC column. A linear gradient of acetonitrile was used. Pooled fractions were lyophilized. The peptide was then characterized by mass spectroscopic and amino acid analyses.

\section{Radiolabeling}

Radiolabeling of TP3939 with ${ }^{64} \mathrm{Cu} .{ }^{64} \mathrm{Cu}$ was obtained either from Washington University School of Medicine, IsoTrace, or Nordion Inc. In a 5-mL siliconized glass test tube, we dispensed $20 \mu \mathrm{g}$ of TP3939 followed by $400 \mu \mathrm{L}$ of glycine buffer $(0.2$ $\mathrm{mol} / \mathrm{L}, \mathrm{pH} 9), \mathrm{SnCl}_{2} 2 \mathrm{H}_{2} \mathrm{O}(100 \mu \mathrm{g}$ in $10 \mu \mathrm{L}), \mathrm{HCl}(0.05 \mathrm{~mol} / \mathrm{L})$, and ${ }^{64} \mathrm{CuCl}_{2}$ (generally $7.4-22.2 \mathrm{mBq}$ or greater) in $1 \mu \mathrm{L}$ of $\mathrm{HCl}$ $(0.1 \mathrm{~mol} / \mathrm{L})$. The reaction mixture was stirred in a vortex mixer and incubated at $90^{\circ} \mathrm{C}$ for $45 \mathrm{~min}(27)$.

Radiolabeling of TP3939 with ${ }^{99 m} T c$. In the present study, ${ }^{99 \mathrm{~m}} \mathrm{Tc}$ preparations were used for cell-binding assays only when ${ }^{64} \mathrm{Cu}$ was not available. This procedure was described previously (27).

Quality Control of Labeled TP3939. The radiochemical purity of ${ }^{99} \mathrm{~m} \mathrm{Tc}$ and ${ }^{64} \mathrm{Cu}-\mathrm{TP} 3939$ was determined using HPLC (Shimadzu Corp.) coupled to an ultraviolet detector, a $\mathrm{NaI}(\mathrm{Tl})$ radioactivity monitor, and a rate meter. A reverse-phase C18 Microbond column $(4.6 \times 250 \mathrm{~mm}$; Varian, Inc. $)$ served as the stationary phase, and a gradient of 2 solvents, $0.1 \%$ trifluoroacetic acid in $\mathrm{H}_{2} \mathrm{O}$ and $0.1 \%$ trifluoroacetic acid in acetonitrile, served as the mobile phase. The gradient was such that $10 \% \mathrm{CH}_{3} \mathrm{CN}$ in aqueous $0.1 \% \mathrm{CF}_{3} \mathrm{CO}_{2} \mathrm{H}$ to $100 \% \mathrm{CH}_{3} \mathrm{CN}$ in $0.1 \% \mathrm{CF}_{3} \mathrm{CO}_{2} \mathrm{H}$ required $32 \mathrm{~min}$ at a flow rate of $1 \mathrm{~mL} / \mathrm{min}$ at $22^{\circ} \mathrm{C}$.

\section{Functional Assay}

In large quantities, VIP functions as a vasodilator and muscle relaxant. The muscle relaxant property was used to compare the biologic activity of TP3939 with that of native $\mathrm{VIP}_{28}$. This assay was based on the binding property of VIP to specific receptors producing a concentration-dependent decrease in the resting tension of the internal anal sphincter (IAS) smooth muscle. The effects of different concentrations of $\mathrm{VIP}_{28}$ and TP3939 were determined until the fall in the basal tension of IAS was maximized.

Preparation of Smooth Muscle Strips. All animal studies were performed in accordance with the protocol approved by the Institutional Animal Care and Use Committee. Two adult Wistar rats were anesthetized and euthanized. The distal anal canal was dissected and immediately transferred to oxygenated Krebs' physiologic solution composed of (mmol/L): $118.07 \mathrm{NaCl}, 4.69$ $\mathrm{KCl}, 2.52 \mathrm{CaCl}_{2}, 1.16 \mathrm{MgSO}_{4}, 1.01 \mathrm{NaH}_{2} \mathrm{PO}_{4}, 25 \mathrm{NaHCO}_{3}$, and 11.10 glucose. The IAS smooth muscle strips (approximately $2 \times$ $10 \mathrm{~mm}$ ) were prepared using our earlier protocol (27).

Measurement of Isometric Tension. The dissected IAS muscle strips were transferred to $37^{\circ} \mathrm{C}, 2-\mathrm{mL}$ muscle baths with Krebs' solution bubbled continuously with a mixture of $95 \% \mathrm{O}_{2}$ and $5 \%$ $\mathrm{CO}_{2}$. One end of the muscle strip was tied firmly to the bottom of the muscle bath, and the other end was attached to an isometric 
force transducer (model FTO3; Grass Instruments). The isometric tension was measured using the PowerLab/8SP data acquisition system and recorded using Chart 4.1.2 (AD Instruments Ltd.). One gram of tension was applied to the muscle strips, which were then allowed to equilibrate for about $1 \mathrm{~h}$ with occasional washings. Only those strips that developed steady tension and relaxed in response to electrical field stimulation during the 1-h period were used. Both optimal length and base line of the muscle strips were determined (28-30).

Drug Response. The effect of different concentrations of TP3939 and the native VIP $_{28}$ on the resting IAS tension was then examined using cumulative concentration responses. The muscle strips were washed continuously for 45-60 min before testing for the concentration-response curve of each agent. To attain maximal relaxation $(100 \%)$, the muscle strips were allowed to interact with ethylenediaminetetraacetic acid $(10 \mathrm{mmol} / \mathrm{L})$. The percentage of maximum fall in the IAS tone was plotted against log concentration of the respective analogue. The inhibitory concentrations of $50 \%$ ( $\mathrm{IC}_{50}$ values), or concentrations at which $50 \%$ of the relaxivity occurred, were calculated.

\section{Human PC Cell Line}

Androgen receptor-positive PC3 PC cells (American Type Culture Collection) were maintained in F-12K (Kaighn's modification of Harris F-12 medium containing $2 \mathrm{mM}$ L-glutamine and $1,500 \mathrm{mg} / \mathrm{L} \mathrm{NaHCO}_{3}$ ) at $37^{\circ} \mathrm{C}$ under $5 \% \mathrm{CO}_{2} / 95 \%$ air. When confluent, the cells were detached using $0.25 \%$ trypsin-ethylenediamine tetraacetic acid and resuspended in the growth medium. Cell concentration was determined using a hemocytometer.

\section{Receptor Affinity Assays}

Using ${ }^{99 m} T c-T P 3939$. PC3 cells $\left(0.5 \times 10^{5}\right.$ cells per well $)$ cultured as described above were seeded into 64 wells. Eight samples of ${ }^{99 \mathrm{~m}}$ Tc-TP3939 at concentrations of $0.01-540 \mathrm{nM}$ were added to the 4 wells and placed for $1 \mathrm{~h}$ in a humidified incubator at $37^{\circ} \mathrm{C}$ and $5 \% \mathrm{CO}_{2}$ with $95 \%$ air. Each experiment was repeated in triplicate. Cold $1 \%$ BSA F-12K medium $(0.5 \mathrm{~mL})$ was added to terminate the incubation. After $5 \mathrm{~min}$, the cells were washed 3 times using the same buffer, and the supernatant from each wash was collected into marked test tubes. The cells were then solubilized with $1 \mathrm{M} \mathrm{NaOH}$ at $37^{\circ} \mathrm{C}$ and collected in separate test tubes. This process was repeated until all solubilized cells were completely collected. The radioactivity in each fraction was then counted in a $\gamma$-counter (Packard 5000 series) obtained with additional 2-in $(5.08-\mathrm{cm})$ lead shielding to minimize septal penetration of high energy $\gamma$ - or $\beta$-rays. These data permitted us to calculate the ratios of bound to free radioactivity and the number of peptide molecules in moles bound to cells. Data were then plotted according to the method of Scatchard (31), and affinity constants (Kd values) were calculated following the guidelines of the Assay Guidance Manual (32).

Using ${ }^{64} \mathrm{CuCl}_{2}$. To determine whether ${ }^{64} \mathrm{CuCl}_{2}$ uptake in $\mathrm{PC} 3$ cells was specific and receptor-mediated, the experiments were performed using the above procedure except that ionic ${ }^{64} \mathrm{CuCl}_{2}$ was used in no-carrier-added form (as delivered by the vendors) or with added $\mathrm{CuCl}_{2}$ carrier of known $\left(10^{-5}-10^{-18} \mathrm{M}\right)$ molarity.

\section{Blood Clearance}

${ }^{64} \mathrm{Cu}$-TP3939 (3.7-4.44 MBq) was administered to each mouse $(n=3)$ through a lateral tail vein, and blood samples (approx- imately $50 \mu \mathrm{L}$ each) were drawn at $1,3,5,10,15,30,45,60,90$, 120,180 , and $240 \mathrm{~min}$ and at $24 \mathrm{~h}$ after administration. A small incision was made in the distal tail to facilitate rapid and reliable blood drawing. Excessive bleeding was prevented by applying gentle pressure for approximately $1 \mathrm{~min}$. Each sample was weighed in an analytical balance (Sartorius, $1602 \mathrm{MP}$ ), and the associated radioactivity was counted in the $\gamma$-counter along with a standard ${ }^{64} \mathrm{Cu}$ solution prepared at the time of injection. The percentage injected dose per gram $(\% \mathrm{ID} / \mathrm{g})$ and its mean $\pm \mathrm{SD}$ in each sample were determined, and data were plotted as a function of time.

\section{In Vivo Stability}

Transchelation of ${ }^{64} \mathrm{Cu}$ from ${ }^{64} \mathrm{Cu}$-TP3939 peptide to mouse plasma proteins was determined using sodium dodecyl sulphate polyacrylamide gel electrophoresis (PAGE) and 18\% Tris-glycine gel (Invitrogen Life Technologies). ${ }^{64} \mathrm{Cu}$-TP3939 was administered through a lateral tail vein, the mouse was euthanized 2-3 min later, $0.5 \mathrm{~mL}$ of blood was collected and centrifuged for 10 min at 2,000 rpm, and serum was isolated. Tris-glycine sodium dodecyl sulphate buffer and deionized water were then added, samples digested at $85^{\circ} \mathrm{C}$ for $2 \mathrm{~min}$, and $30 \mu \mathrm{L}$ of the mixture loaded into a well. A protein mixture of various molecular weights was loaded into the first well. ${ }^{64} \mathrm{Cu}-\mathrm{TP} 3939$ and ${ }^{64} \mathrm{CuCl}_{2}$ incubated at $25^{\circ} \mathrm{C}$ with human serum albumin $(5 \mathrm{mg} / \mathrm{mL}, 20 \mu \mathrm{L})$ and treated as above, as well as ${ }^{64} \mathrm{CuCl}_{2}$ alone, were loaded into separate wells. All samples loaded on 2 gels were analyzed at $160 \mathrm{~V}$ maintained for $45 \mathrm{~min}$. One gel was stained with Coomassie blue, destained, cut into $0.5-\mathrm{cm}$ sections, marked for appropriate molecular weight, and counted for radioactivity in the $\gamma$-counter. The other gel was exposed to a phosphor imaging plate for $18 \mathrm{~h}$, then stained with Coomassie blue, destained, cut, and counted for radioactivity. The plate was processed using Fujifilm Fluorescent Image Analyzer, FLA-5000 (Image Gauge, version 4.0). The percentage of ${ }^{64} \mathrm{Cu}$ associated with each protein band was determined.

\section{Inducing Human Prostate Tumors in Athymic Nude Mice}

Approximately $4 \times 10^{6}$ viable PC3 cells in $200 \mu \mathrm{L}$ were aseptically implanted subcutaneously in the right thigh of each male nude mouse ( $n=5$ per group) weighing 20-25 g. A sterile $1-\mathrm{mL}$ syringe coupled to a sterile $27-\mathrm{G}$ needle was used. The tumors were allowed to grow to no more than $0.5 \mathrm{~cm}$ in diameter.

\section{TRAMP Mice}

Two TRAMP mice were obtained (Jackson Laboratory) at the age of $9 \mathrm{wk}$ and studied serially using either ${ }^{18} \mathrm{~F}-\mathrm{FDG}$ or ${ }^{64} \mathrm{Cu}-$ TP3939, which was administered $24 \mathrm{~h}$ after allowing complete decay of ${ }^{18} \mathrm{~F}$.

\section{Imaging Mice}

PET Imaging. Approximately 3.88-4.07 MBq of ${ }^{64} \mathrm{Cu}-\mathrm{TP} 3939$ or ${ }^{64} \mathrm{CuCl}_{2}$ was injected through a lateral tail vein of each mouse. TRAMP mice were imaged once a month from the age of $11 \mathrm{wk}$ until sacrificed 5 mo later. One day before each imaging with ${ }^{64} \mathrm{Cu}$-TP3939, TRAMP mice received approximately $14.8-18.5$ $\mathrm{MBq}$ of ${ }^{18} \mathrm{~F}-\mathrm{FDG}$ intravenously and were imaged $1 \mathrm{~h}$ later. The athymic nude mice with PC3 xenografts were imaged 4 and $24 \mathrm{~h}$ after injection of 5.5-7.4 MBq of ${ }^{64} \mathrm{Cu}-\mathrm{TP} 3939$. The mice were anesthetized using ketamine, xylazine, and acepromazine. The PET images were acquired in full 3-dimensional mode for $15 \mathrm{~min}$ 


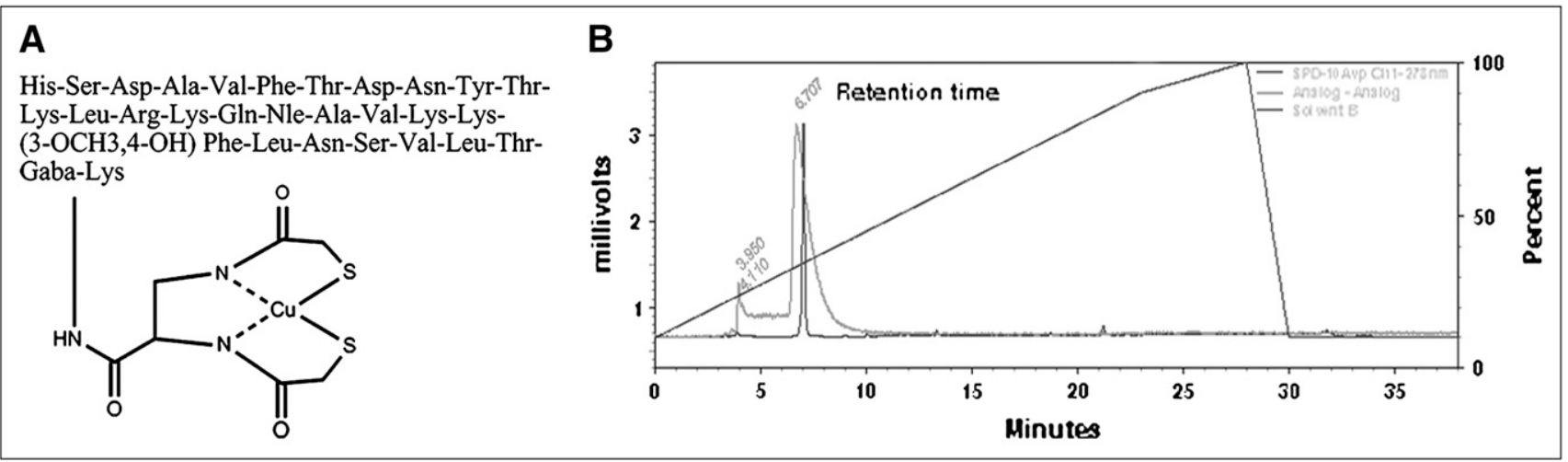

FIGURE 1. Schematic presentation of Cu-TP3939 (A) and HPLC eluates of ${ }^{64} \mathrm{Cu}-\mathrm{TP} 3939$ at $6.7 \mathrm{~min}$ and free ${ }^{64} \mathrm{Cu}$ at $3.9 \mathrm{~min}(\mathrm{~B})$. Diagonal line represents gradient.

using a Philips Mosaic small-animal scanner. Up to 27 million counts were collected. Images were reconstructed using a fully 3-dimensional iterative reconstruction algorithm giving a pixel size of $1 \mathrm{~mm}$. Region-of-interest analysis was performed digitally.

CT Imaging. Noncontrast CT imaging was performed using the MicroCAT II (ImTek Inc.) small-animal CT scanner. X-rays are generated at $80 \mathrm{kVp}$ and $500 \mu \mathrm{A}$. The $\mathrm{x}$-ray source and the detector are rotated around the subject to produce a transaxial field of view of $51.2 \mathrm{~mm}$ and an axial field of view of $76.8 \mathrm{~mm}$. Images were reconstructed into $0.2 \times 0.2 \times 0.2 \mathrm{~mm}$ voxels using a Feldkamp cone-beam reconstruction algorithm.

PET and CT images was coregistered using an internally developed automated mutual information rigid registration algorithm. Volumes of interest were defined by drawing multislice regions of interest on the tumor (at $50 \%$ of maximum voxels) and the contralateral soft tissue. Average ratios of tumor to muscle uptake were calculated.

\section{Tissue Distribution}

${ }^{64} \mathrm{Cu}-\mathrm{TP} 3939,0.37-0.55 \mathrm{MBq}$, was administered intravenously through a lateral tail vein in $200 \mu \mathrm{L}$ of the preparation. Radio-

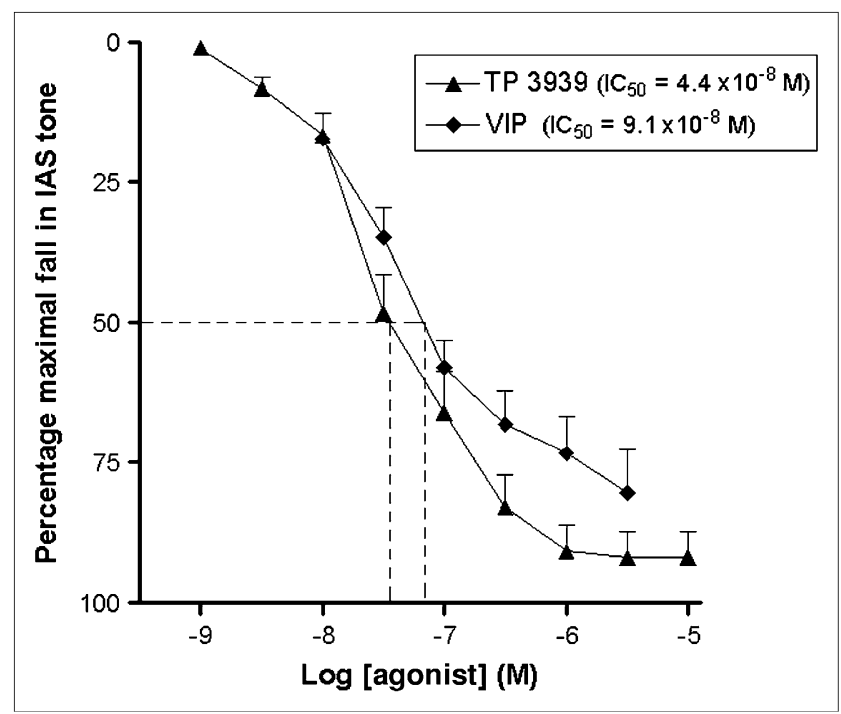

FIGURE 2. Muscle relaxivity assays as function of concentration for $\mathrm{VIP}_{28}$ and its analogue TP3939. $\mathrm{IC}_{50}$ values are calculated as concentration at which $50 \%$ relaxivity occurred. activity in the syringe before and after administration was measured in an energy-calibrated dose calibrator (CRC-15; Capintec), and the exact quantity received by each animal was determined. At 4 and $24 \mathrm{~h}$ after injection $(n=5)$, the animals were killed by $\mathrm{CO}_{2}$ inhalation. Tissues, including normal prostate (aided by light microscopy), were dissected, washed free of blood, blotted dry, and weighed, and the associated radioactivity was counted in the $\gamma$-counter. A $20 \%$ energy window was used. Results were calculated as $\% \mathrm{ID} / \mathrm{g}$ of tissue and analyzed statistically using the Student $t$ test. Similar studies were performed on additional groups of 5 mice each using ${ }^{64} \mathrm{CuCl}_{2},(0.92-1.11 \mathrm{MBq})$ in acetate buffer (0.1 M, pH 6.5) as a control.

The 2 TRAMP mice imaged periodically, as described earlier, were sacrificed when ${ }^{64} \mathrm{Cu}$-TP3939 PET showed the PC in 1 (TRAMP II) mouse. The lower abdomen was surgically exposed and photographed, and then the organs, including prostate gland and seminal vesicles, were extirpated. These were immediately weighed and placed in $10 \%$ formaldehyde in phosphate-buffered saline. All tissues, including prostate glands, were counted for ${ }^{64} \mathrm{Cu}$ radioactivity. The prostate and seminal vesicles were embedded in paraffin blocks so that $10-\mu \mathrm{m}$-thick histologic slices could be obtained, which were then stained with hematoxylin and eosin, examined under a microscope, and photomicrographed.

\section{Receptor-Blocking Study}

In another group of athymic nude mice $(n=5), 40 \mu \mathrm{g}$ of cold TP3939 were administered through a lateral tail vein. Thirty minutes later, $0.37-0.55 \mathrm{MBq}$ of ${ }^{64} \mathrm{Cu}$-TP3939 were administered. PET imaging was performed, and tissue distribution was performed $24 \mathrm{~h}$ later.

\section{RESULTS}

\section{Synthesis}

The amino acid sequence and the schematic diagram of TP3939 are given in Figure 1A. The observed and calcu-

TABLE 1

$\mathrm{IC}_{50}$ and $\mathrm{Kd}$ Values

\begin{tabular}{lcc}
\hline Peptide & $\mathrm{IC}_{50}$ & $\mathrm{Kd}$ \\
\hline TP3939 & $4.4 \times 10^{-8} \mathrm{M}$ & $0.77 \times 10^{-9} \mathrm{M}$ \\
VIP $_{28}$ & $9.1 \times 10^{-8} \mathrm{M}$ & $15.0 \times 10^{-9} \mathrm{M}$ \\
\hline
\end{tabular}


FIGURE 3. Scatchard plots for ${ }^{99 m T c-}$ TP3939 binding to PC3 cells known to express VPAC1 oncogene receptors. Kd value was $0.77 \times 10^{-9} \mathrm{M}$.

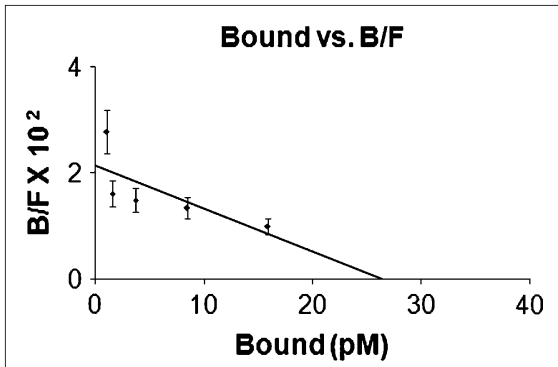

lated molecular weights were 3,939.4 and 3,939 Da, respectively. The purity of the peptide was $96.8 \%$.

\section{Radiochemical Purity}

The labeling efficiency of ${ }^{99 \mathrm{~m}}$ Tc-TP3939 as determined by HPLC was $98 \% \pm 2 \%$. Retention time for ${ }^{64} \mathrm{Cu}$-TP3939 was $6.7 \mathrm{~min}$. A typical HPLC elution curve is displayed in Figure 1B.

\section{Functional Response}

The $\mathrm{IC}_{50}$ values for TP3939 and $\mathrm{VIP}_{28}$ were $4.4 \times 10^{-8} \mathrm{M}$ and $9.1 \times 10^{-8} \mathrm{M}$, respectively (Fig. 2; Table 1 ).

\section{Receptor Affinity Assays}

The $\mathrm{Kd}$ for ${ }^{64} \mathrm{Cu}$-TP3939 was $0.77 \times 10^{-9} \mathrm{M}$ (Fig. 3; Table 1). The $\mathrm{IC}_{50}$ and the $\mathrm{Kd}$ values suggest that the biologic activity of TP3939 was not compromised, compared with that of the $\mathrm{VIP}_{28}$. The results of ${ }^{64} \mathrm{CuCl}_{2}$ affinity assays for PC3 cells (Fig. 4) revealed nonsaturable and nonspecific binding. Therefore $\mathrm{Kd}$ values were not determined.

\section{Blood Clearance}

Blood clearance for ${ }^{64} \mathrm{Cu}$-TP3939 (Fig. 5) was biphasic, with an $\alpha$ half-life of approximately $3.1 \mathrm{~min}(70 \%)$ and a $\beta$ half-life of approximately $120 \mathrm{~min}$.

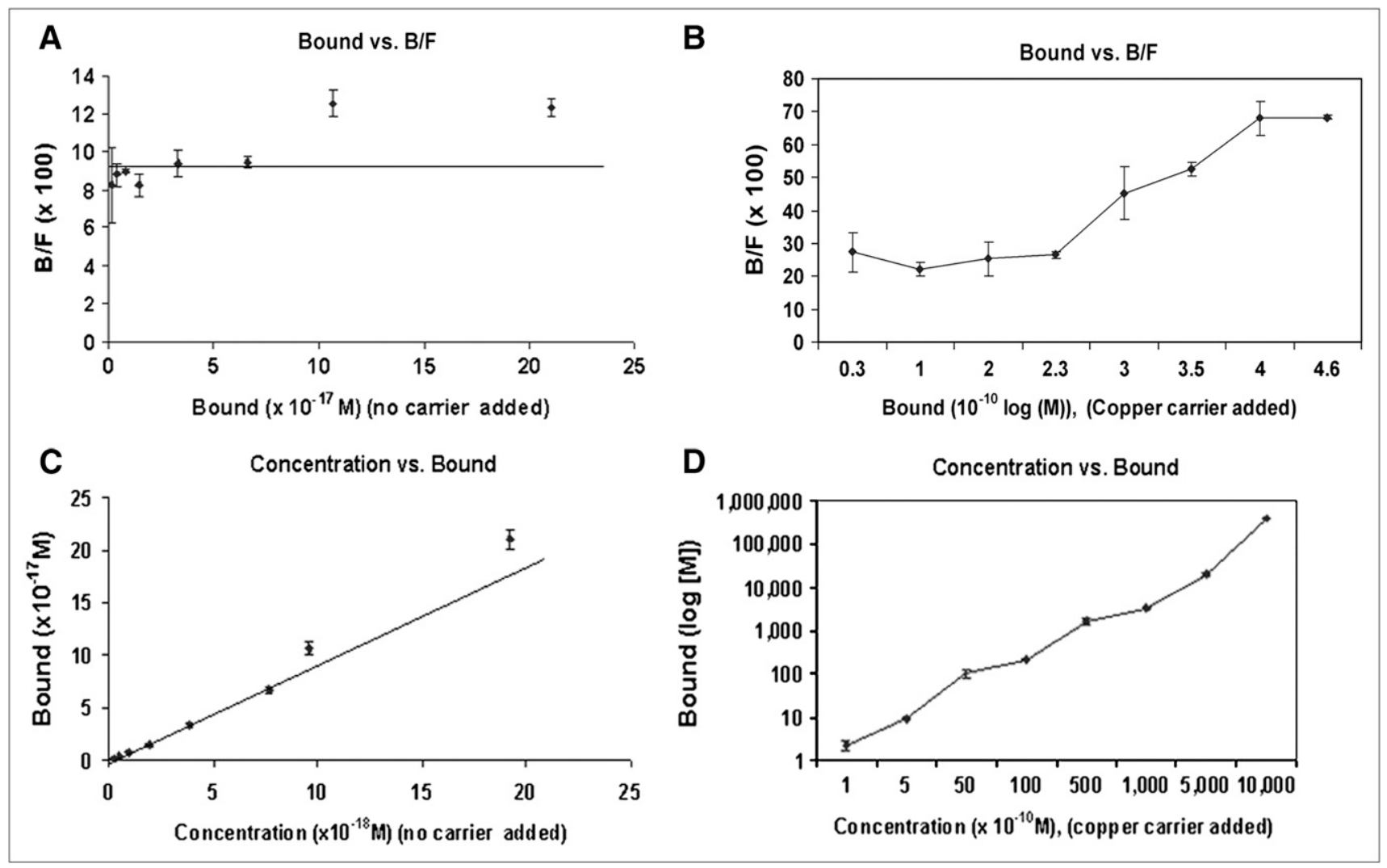

FIGURE 4. ${ }^{64} \mathrm{CuCl}_{2}$ binding assays for $\mathrm{PC} 3$ cells performed with added copper carrier (B and $\left.\mathrm{D}\right)$ and with no ${ }^{64} \mathrm{CuCl}_{2}$ carrier added ( $A$ and $\mathrm{C}$ ). In either case, data reveal nonsaturable, nonspecific binding. 


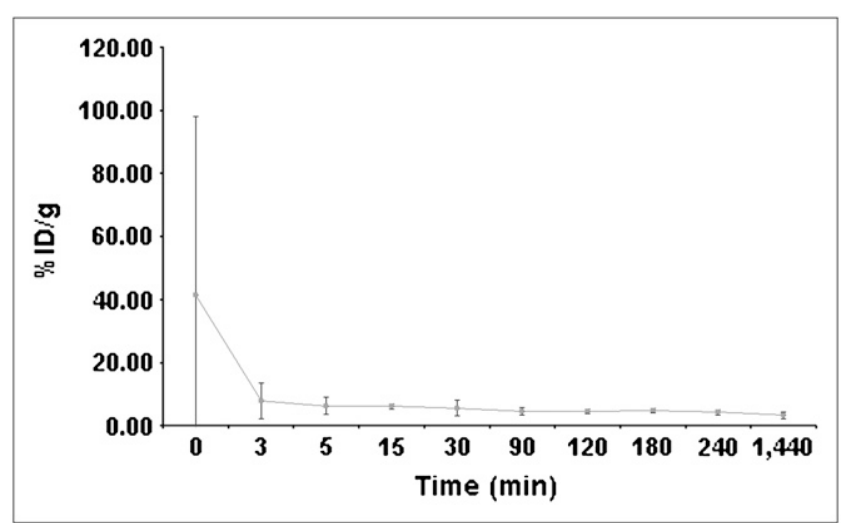

FIGURE 5. Blood clearance curve of ${ }^{64} \mathrm{Cu}-\mathrm{TP} 3939$ in athymic nude mice $(n=3)$.

\section{In Vivo Stability}

Photographs of Coomassie blue-stained protein bands and the corresponding autoradiograph are given in Figures 6A and $6 \mathrm{~B}$, respectively. The quantitative data of ${ }^{64} \mathrm{Cu}$ distribution in various bands (Table 2) show that approximately $83 \%$ of ${ }^{64} \mathrm{Cu}$ was associated with a molecular weight of $4 \mathrm{kDa}$, which is that of TP3939. The remaining radioactivity was associated with proteins of molecular weights of $6 \mathrm{kDa}$ and above (lane 1). Negligible $(<3 \%)$ transchelation of ${ }^{64} \mathrm{Cu}$ to protein was noted when either ${ }^{64} \mathrm{Cu}-\mathrm{TP} 3939$ or ${ }^{64} \mathrm{CuCl}_{2}$ was incubated with human serum albumin (Table 2, lanes 2 and 3 ).

\section{Imaging Nude and TRAMP Mice}

PET images revealed high uptake in PC3 tumors (Fig. 7A; Table 3). Ratios of tumor to contralateral muscle as determined by region-of-interest analysis were 3.357 and 4.205 at 4 and $24 \mathrm{~h}$, respectively, for ${ }^{64} \mathrm{Cu}-\mathrm{TP} 3939$. The corresponding ratio for ${ }^{18} \mathrm{~F}-\mathrm{FDG}$ at $1 \mathrm{~h}$ after injection was 1.66 (Supplemental Fig. 1 [supplemental materials are available online only at http://jnm.snmjournals.org]). In the TRAMP
II mouse with grade IV prostate intraepithelial neoplasia, the lesion was clearly imaged with ${ }^{64} \mathrm{Cu}-\mathrm{TP} 3939$ but not with $\mathrm{CT}$ or ${ }^{18} \mathrm{~F}$-FDG (Fig. 7B). ${ }^{64} \mathrm{Cu}$-TP3939 activity adjacent to the prostate was associated with feces $(0.77 \% \mathrm{ID} / \mathrm{g})$. The prostate gland in mouse 1 with grade II hyperplasia was not visualized either with ${ }^{64} \mathrm{Cu}$-TP3939 or with ${ }^{18} \mathrm{~F}$-FDG. The high bladder uptake of ${ }^{18} \mathrm{~F}-\mathrm{FDG}$ was visible. In contrast, bladder activity was absent with ${ }^{64} \mathrm{Cu}-\mathrm{TP} 3939$ (Fig. 7B).

\section{Tissue Distribution}

The 4- and $24-\mathrm{h}{ }^{64} \mathrm{Cu}-\mathrm{TP} 3939$ data given in Table 3 show that ${ }^{64} \mathrm{Cu}-\mathrm{TP} 3939$ uptake in $\mathrm{PC}$ was $7.48 \pm 3.63 \% \mathrm{ID} / \mathrm{g}$ at $4 \mathrm{~h}$ and $5.78 \pm 0.66 \% \mathrm{ID} / \mathrm{g}$ at $24 \mathrm{~h}(P=0.47)$. The corresponding radioactivity ratios for tumor to muscle were $3.98 \pm 1.43$ and $5.17 \pm 1.32$, respectively, and the tumor-to-blood ratios were $1.94 \pm 0.66$ and $2.46 \pm 0.45$, respectively. There is progressive elimination of the activity through the kidneys, lungs, and liver. The primary route of excretion was feces and not urine.

The 4- and 24-h tumor uptake of ${ }^{64} \mathrm{CuCl}_{2}$ was $4.79 \pm$ $0.34 \% \mathrm{ID} / \mathrm{g}$ and $4.03 \pm 0.83 \% \mathrm{ID} / \mathrm{g}$, respectively (Table 4 ), significantly lower $(24 \mathrm{~h}, P=0.02)$ than that of ${ }^{64} \mathrm{Cu}-$ TP3939.

The uptake of ${ }^{64} \mathrm{CuCl}_{2}$ in all tissues except the kidneys was also significantly lower than that of ${ }^{64} \mathrm{Cu}$ TP3939. Tumor-to-muscle and tumor-to-blood ratios, however, were not statistically significantly different.

The uptake of ${ }^{64} \mathrm{Cu}$-TP3939 in normal prostate gland $(n=5)$ was $1.9 \pm 0.5 \% \mathrm{ID} / \mathrm{g}$ at $4 \mathrm{~h}$ after injection and $2.1 \pm$ $0.35 \% \mathrm{ID} / \mathrm{g}$ at $24 \mathrm{~h}$. The respective ratios were 1 and 1.8 for normal prostate to muscle and 4 and 2.7 for PC tumor to normal prostate.

\section{Receptor-Blocking Study}

After blocking of the VPAC1 receptors, tumor uptake was significantly decreased from $5.78 \pm 0.66$ to $1.84 \pm$ $0.44 \% \mathrm{ID} / \mathrm{g}$ at $24 \mathrm{~h}(P=0.01)$. All other tissues also had

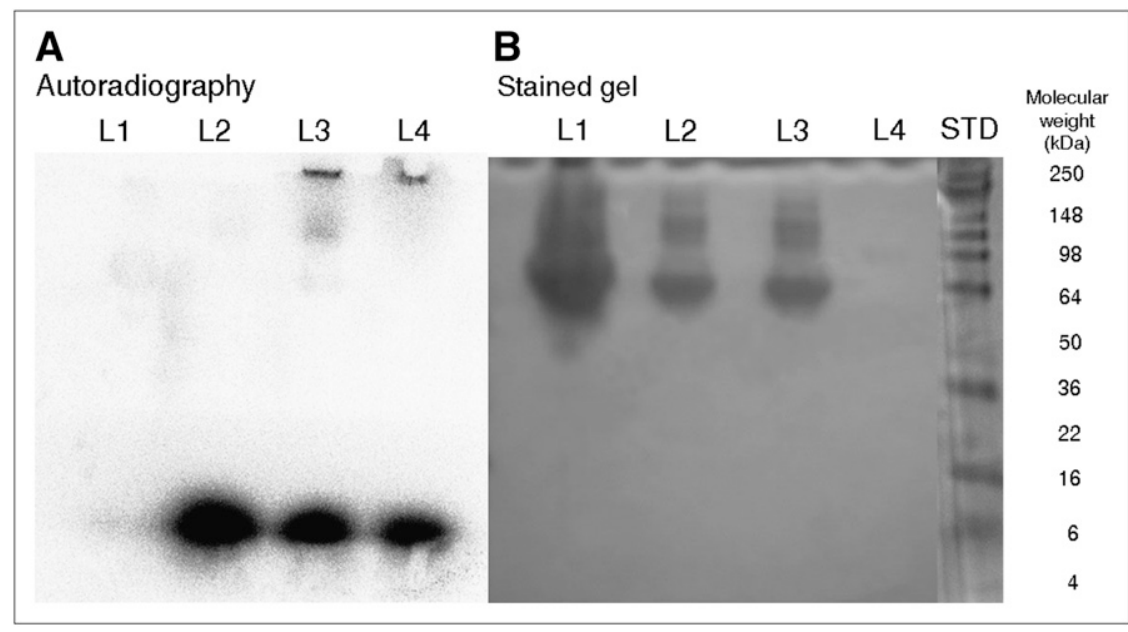

FIGURE 6. Autoradiography (A) and gel stained with Coomassie blue (B) after PAGE analysis of serum isolated from mouse after intravenous administration of ${ }^{64} \mathrm{Cu}$-TP3939. Lane 1 (L1) $={ }^{64} \mathrm{Cu}$ TP3939 in mouse serum; lane 2 (L2) = ${ }^{64} \mathrm{Cu}$-TP3939 with human serum albumin; lane $3(\mathrm{~L} 3)={ }^{64} \mathrm{CuCl}_{2}$ with human serum albumin; lane $4(\mathrm{~L} 4)={ }^{64} \mathrm{CuCl}_{2}$; STD $=$ molecular weight standard. 
TABLE 2

PAGE Analysis: Estimated Molecular Weights and \% Radioactivity Associated with Them

\begin{tabular}{|c|c|c|c|c|}
\hline $\begin{array}{c}\text { Molecular } \\
\text { weight (kDa) }\end{array}$ & $\begin{array}{l}\text { Lane 1: }{ }^{64} \mathrm{Cu}-\mathrm{TP} 3939 \\
\text { in serum (in vivo) }(\%)\end{array}$ & $\begin{array}{c}\text { Lane } 2:{ }^{64} \mathrm{Cu}-\mathrm{TP} 3939 \\
\text { with HAS (\%) }\end{array}$ & $\begin{array}{c}\text { Lane } 3:{ }^{64} \mathrm{CuCl}_{2} \\
\text { with HAS (\%) }\end{array}$ & $\begin{array}{l}\text { Lane 4: } \\
{ }^{64} \mathrm{CuCl}_{2}(\%)\end{array}$ \\
\hline$>98$ & 10.08 & 0.47 & 2.25 & 2.46 \\
\hline $50-64$ & 4.03 & 0.25 & 0.17 & 0.38 \\
\hline $6-16$ & 1.23 & 0.09 & 0.16 & 0.45 \\
\hline$<4-4$ & 83.91 & 99.19 & 97.42 & 96.74 \\
\hline
\end{tabular}

$\mathrm{HSA}=$ human serum albumin.

significantly $(P<0.05)$ diminished uptake of ${ }^{64} \mathrm{Cu}$ TP3939 (Table 5).

\section{DISCUSSION}

Scintigraphy is a prominent and prudent modality that plays a major role in molecular imaging. It can noninvasively visualize and measure the gene product overex- pressed on the malignant cells, while imparting low levels of radiation dose. The high sensitivity and spatial resolution of current PET systems provide excellent localization of occult lesions that warrant aggressive therapy. PET can also detect recurrent disease and monitor the effectiveness of therapy.

VPAC1 receptors are overexpressed in all PC (16-18). VIP, a 28-amino-acid peptide, has high affinity for VPAC

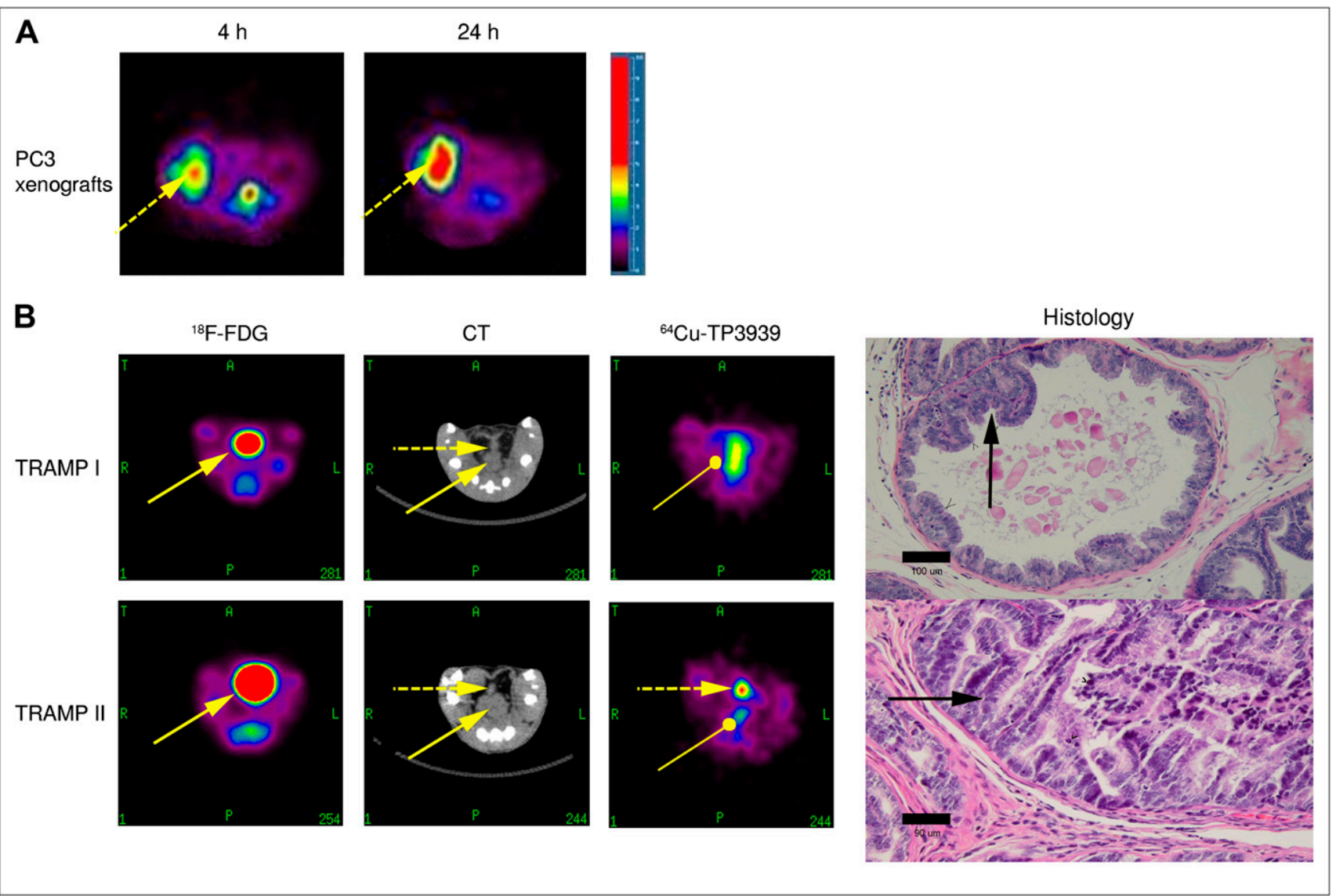

FIGURE 7. (A) Transaxial PET images demonstrate high uptake of ${ }^{64} \mathrm{Cu}-\mathrm{TP} 3939$ in xenografted PC3 tumor in right flank of athymic nude mouse (dashed arrows). Images were taken 4 and $24 \mathrm{~h}$ after injection of ${ }^{64} \mathrm{Cu}-\mathrm{TP} 3939$. (B) Presented from left to right are composite of ${ }^{18} \mathrm{~F}-\mathrm{FDG}, \mathrm{CT}$, and ${ }^{64} \mathrm{Cu}$-TP3939 images obtained from TRAMP I and TRAMP II transgenic mice and histology of their corresponding prostate glands. One-hour ${ }^{18} \mathrm{~F}-\mathrm{FDG}$ images show only bladder activity (solid arrow). In 4-h CT images, dashed and solid arrows show prostate and bladder, respectively. Four-hour ${ }^{64} \mathrm{Cu}$-TP3939 transaxial PET images show only colon activity (oval-head arrow) in TRAMP I, whereas in TRAMP II, significant PC uptake (dashed arrow) and negligible colon uptake are seen. Prostate histology $(\times 40)$ indicates grade II and grade IV prostate intraepithelial neoplasia in TRAMP I and TRAMP II, respectively (black arrows). Tumor with histology grade IV is visible with ${ }^{64} \mathrm{Cu}-\mathrm{TP} 3939$ but not with ${ }^{18} \mathrm{~F}-\mathrm{FDG}$. 
TABLE 3

Tissue Distribution (\%ID/g) of ${ }^{64} \mathrm{Cu}$-TP3939 in PC3 Tumor-Bearing Nude Mice $(n=5)$

\begin{tabular}{lrrr}
\hline \multicolumn{1}{c}{ Tissue } & \multicolumn{1}{c}{$4 \mathrm{~h}$} & $24 \mathrm{~h}$ & $P$ \\
\hline Muscle & $1.94 \pm 0.85$ & $1.15 \pm 0.18$ & 0.17 \\
Intestine & $11.00 \pm 1.64$ & $7.67 \pm 2.48$ & 0.06 \\
Heart & $9.13 \pm 5.63$ & $4.14 \pm 0.65$ & 0.19 \\
Lungs & $34.31 \pm 9.76$ & $19.93 \pm 5.56$ & 0.06 \\
Blood & $3.85 \pm 1.14$ & $2.38 \pm 0.26$ & 0.07 \\
Spleen & $19.22 \pm 9.13$ & $3.56 \pm 0.38$ & 0.03 \\
Kidneys & $18.38 \pm 9.95$ & $10.06 \pm 0.42$ & 0.21 \\
Liver & $55.00 \pm 12.62$ & $27.58 \pm 2.18$ & 0.01 \\
Tumor & $7.48 \pm 3.63$ & $5.78 \pm 0.66$ & 0.47 \\
T/M ratio & $3.98 \pm 1.43$ & $5.17 \pm 1.32$ & 0.29 \\
T/B ratio & $1.94 \pm 0.66$ & $2.46 \pm 0.45$ & 0.28 \\
\hline
\end{tabular}

receptors. We designed and synthesized a VIP analogue, TP3939, for efficient labeling with ${ }^{64} \mathrm{Cu}$ for PET imaging of PC. The physical characteristics of ${ }^{64} \mathrm{Cu}$ permit PET imaging for up to $24 \mathrm{~h}$ after injection without having excessive radioactivity decay occur. ${ }^{64} \mathrm{Cu}$ in cupric form facilitated strong chelation with the $\mathrm{N}_{2} \mathrm{~S}_{2}$ chelating moiety and provided high labeling efficiency $(95.43 \% \pm 3.78 \%$, $n=6$ ) allowing us to use the labeled probe without further purification. The labeling efficiency with ${ }^{99 \mathrm{~m}} \mathrm{Tc}$ was also equally high and provided a choice for SPECT (27).

Our data demonstrate that TP3939 analogue retained the biologic activity of $\operatorname{VIP}_{28}\left(\mathrm{IC}_{50}=0.44 \times 10^{-9} \mathrm{M}\right.$ vs. $0.9 \times$ $\left.10^{-9} \mathrm{M}\right)$ and high affinity $\left(\mathrm{Kd}=0.77 \times 10^{-9} \mathrm{M}\right.$ vs. $15 \times$ $10^{-9} \mathrm{M}$ for VIP) for VPAC receptors. The blood clearance of ${ }^{64} \mathrm{Cu}$-TP3939 was rapid and supported early imaging. The in vivo stability, as determined by PAGE analysis of serum isolated from mice receiving ${ }^{64} \mathrm{Cu}-\mathrm{TP} 3939$, demonstrated that the peptide was stable in vivo and that approximately only $15 \%$ of the radioactivity was transchelated to proteins of molecular weights more than $98 \mathrm{kDa}$ (Figs. 6A and 6B). For this analysis, we obtained the blood from mice within only 4 min of intravenous injection of ${ }^{64} \mathrm{Cu}-\mathrm{TP} 3939$ because its blood clearance is rapid (half-life, $3.5 \mathrm{~min}$ ).

TABLE 4

Tissue Distribution (\%ID/g) of ${ }^{64} \mathrm{CuCl}_{2}$ in PC3 Tumor-Bearing Nude Mice $(n=5)$

\begin{tabular}{lrrr}
\hline \multicolumn{1}{c}{ Tissue } & \multicolumn{1}{c}{$4 \mathrm{~h}$} & $24 \mathrm{~h}$ & $P$ \\
\hline Muscle & $0.69 \pm 0.21$ & $0.86 \pm 0.10$ & 0.14 \\
\hline Intestine & $8.84 \pm 1.30$ & $4.58 \pm 0.76$ & 0.00 \\
Heart & $3.66 \pm 0.43$ & $3.38 \pm 0.28$ & 0.25 \\
Lungs & $10.17 \pm 1.95$ & $6.32 \pm 1.57$ & 0.01 \\
Blood & $1.73 \pm 0.30$ & $1.32 \pm 0.14$ & 0.03 \\
Spleen & $2.26 \pm 0.21$ & $1.84 \pm 0.32$ & 0.04 \\
Kidneys & $9.18 \pm 0.79$ & $8.38 \pm 1.47$ & 0.32 \\
Liver & $19.30 \pm 4.37$ & $19.95 \pm 4.52$ & 0.82 \\
Tumor & $4.79 \pm 0.34$ & $4.03 \pm 0.83$ & 0.10 \\
\hline T/M ratio & $7.40 \pm 1.71$ & $4.73 \pm 1.19$ & 0.02 \\
\hline T/B ratio & $2.81 \pm 0.33$ & $3.04 \pm 0.43$ & 0.37 \\
\hline
\end{tabular}

TABLE 5

Tissue Distribution (\%ID/g) of ${ }^{64} \mathrm{Cu}$-TP3939 in Mice Bearing PC3 Xenografts $(n=5,24 \mathrm{~h})$

\begin{tabular}{lrrr}
\hline Tissue & Receptors unblocked & Receptors blocked & $P$ \\
\hline Muscle & $1.15 \pm 0.18$ & $0.65 \pm 0.11$ & 0.01 \\
Intestine & $7.67 \pm 2.48$ & $3.90 \pm 0.50$ & 0.01 \\
Heart & $4.14 \pm 0.65$ & $2.70 \pm 0.64$ & 0.02 \\
Lungs & $19.93 \pm 5.56$ & $7.01 \pm 2.79$ & 0.01 \\
Blood & $2.38 \pm 0.26$ & $1.35 \pm 0.30$ & 0.01 \\
Spleen & $3.56 \pm 0.38$ & $1.60 \pm 0.24$ & 0.01 \\
Kidneys & $10.06 \pm 0.42$ & $5.24 \pm 0.96$ & 0.01 \\
Liver & $27.58 \pm 2.18$ & $12.44 \pm 3.57$ & 0.01 \\
Tumor & $5.78 \pm 0.66$ & $1.84 \pm 0.44$ & 0.01 \\
T/M ratio & $5.17 \pm 1.32$ & $2.91 \pm 0.91$ & 0.03 \\
T/B ratio & $2.46 \pm 0.45$ & $1.43 \pm 0.56$ & 0.04 \\
\hline
\end{tabular}

Serum from blood drawn anytime after this would not have enough radioactivity in the small volume $(30 \mu \mathrm{L})$ of the sample to be loaded on the gel for PAGE. It is for this reason that we incubated ${ }^{64} \mathrm{Cu}-\mathrm{TP} 3939$ with human serum albumin for $30 \mathrm{~min}$, by which more than $97 \%$ of the activity remained associated with TP3939 (Figs. 6A and $6 \mathrm{~B}$, lane 3 ). This is a strong testimony to the in vivo stability of this probe and is consistent with the previously reported $\mathrm{N}_{2} \mathrm{~S}_{2}{ }^{64} \mathrm{Cu}$ complex for in vivo applications (33). No radioactivity associated with $\mathrm{Cu} / \mathrm{Zn}$ peroxidase dismutase (molecular weight, $30 \mathrm{kDa}$ ) was noted (34). Although ${ }^{64} \mathrm{Cu}$-DOTA transchelation has been reported in the rat $(35,36)$, it has not been observed in mice in our laboratory (37). Nevertheless, the early radioactivity uptake in the liver, spleen, kidneys, and lung in these mice was high. However, it clears as a function of time (Table 3) and may thereby minimize the radiation dose to these organs. The primary route of excretion is fecal, not urinary. The normal organ uptake may be related to receptor expression. However, this notion has not yet been confirmed in our laboratory.

The PET images unequivocally delineated the xenografted PC in nude mice (Fig. 7A) and the spontaneous, occult PC in a TRAMP II mouse (Fig. 7B). The PC in TRAMP II was not delineated by ${ }^{18} \mathrm{~F}-\mathrm{FDG}$. Furthermore, ${ }^{64} \mathrm{Cu}$-TP3939 did not detect prostate with hyperplasia in TRAMP I. These data suggest not only the usefulness of ${ }^{64} \mathrm{Cu}-\mathrm{TP} 3939$ for PET imaging of PC but also its specificity. After receptor blocking, there was marked suppression in tumor uptake, from $5.78 \pm 0.66$ to $1.84 \pm 0.44(P=0.01)$ at $24 \mathrm{~h}$, affirming the specificity of TP3939 to the VPAC1 receptors. Tissue uptake in other organs was also significantly $(P<0.05)$ diminished.

Table 3 shows high $(7.48 \pm 3.63 \% \mathrm{ID} / \mathrm{g})$ tumor uptake of ${ }^{64} \mathrm{Cu}$-TP3939 at $4 \mathrm{~h}$, which was not significantly different $(P=0.47)$ at $24 \mathrm{~h}$ after injection. These data suggest that a 55.5-MBq injection should have approximately $4 \mathrm{MBq}$ of the ${ }^{64} \mathrm{Cu}$ per gram of $\mathrm{PC}$ lesions, sufficient for PET imaging in humans and imparting minimal radiation burden to all target organs. The high tumor uptake, rapid blood clearance, and 
lack of radioactivity in the bladder are expected to allow early imaging of PC. Relatively rapid elimination via feces will further minimize the radiation burden to the other organs.

Recently, ${ }^{64} \mathrm{CuCl}_{2}$ was reported to be taken up in experimental PC 3 tumors, and this uptake was attributed to a human copper transporter 1 (hCTr 1) mechanism (15). Our data given in Table 4 confirm $4.03 \pm 0.83 \% \mathrm{ID} / \mathrm{g}$ uptake in PC3 tumors at the same time after injection. However, the uptake was nonspecific (Fig. 5) and significantly $(P=$ 0.02) less than that of ${ }^{64} \mathrm{Cu}-\mathrm{TP} 3939$. In contrast, the ${ }^{64} \mathrm{CuCl}_{2}$ uptake in T47D and MCF7 human BC tumor model was less than $2 \% \mathrm{ID} / \mathrm{g}$ (37). Klomp et al (38), using immunofluorescence studies, have reported that "subcellular hCTr 1 localization differed markedly between cell types." This finding is consistent with our observation between the 3 cell lines we have studied with ${ }^{64} \mathrm{CuCl}_{2}$. Eisses et al (39) have related this phenomenon to the regulation of copper exit pathways in which relocation of ATP 7A plays a major role. Irrespective of the mechanism by which some cells ingress copper and retain it and others do not, it is reasonable to conclude that the use of ${ }^{64} \mathrm{CuCl}_{2}$ creates uncertainty about its reliable uptake in $\mathrm{PC}$ and renders it nonspecific for imaging tumors.

In our previous work, another (GAGG chelating moiety) VIP analogue (TP3654) labeled with ${ }^{99 \mathrm{~m} T c}$ was investigated for imaging breast cancer. Breast cancer also overexpresses VPAC1 receptors. Tumor uptake of this agent was only $0.2 \% \mathrm{ID} / \mathrm{g}$. However, the agent, in a feasibility study in humans, demonstrated excellent sensitivity and specificity (40). Moreover, it correctly detected breast cancer that was not detected by ${ }^{99 \mathrm{~m}} \mathrm{Tc}$-sestamibi. These findings provide optimism for the use of ${ }^{64} \mathrm{Cu}-\mathrm{TP} 3939$ in humans not only for imaging PC but also for detecting its recurrence, detecting metastatic lesions, and determining the effectiveness of therapeutic intervention. Similarly, it is possible to replace ${ }^{64} \mathrm{Cu}$ with ${ }^{67} \mathrm{Cu}$-TP3939 for therapy.

\section{CONCLUSION}

We conclude that ${ }^{64} \mathrm{Cu}$-TP3939 is worthy of further evaluation for PET imaging of human PC and its metastatic or recurrent lesions and for determining the efficacy of its therapeutic treatment.

\section{ACKNOWLEDGMENT}

This work was supported in part by grant CA 109231 from the National Institutes of Health.

\section{REFERENCES}

1. Jemal A, Siegel R, Ward E, Murray T, Xu J, Thun MJ. Cancer statistics. $C A$ Cancer J Clin. 2007;57:43-66.

2. Meikle AW, Smith JA Jr. Epidemiology of prostate cancer. Urol Clin North Am. 1990;17:709-718.

3. Smith RA, Cokkinides V, Eyre HJ. American Cancer Society guidelines for the early detection of cancer. CA Cancer J Clin. 2006;56:11-25.
4. Catalona WJ, Smith DS, Ratliff TL, et al. Measurement of prostate-specific antigen in serum as a screening test for prostate cancer. N Engl J Med. 1991;324: 1156-1161.

5. Catalona WJ, Smith DS, Ratliff TL, Basler JW. Detection of organ-confined prostate cancer is increased through use of prostate-specific antigen-based screening. JAMA. 1993;270:948-954.

6. Catalona WJ, Richie JP, deKernion JB, et al. Comparison of prostate specific antigen concentration versus prostate specific antigen density in the early detection of prostate cancer: receiver operating characteristic curves. J Urol. 1994;152:2031-2036.

7. Yu KK, Hricak H. Imaging prostate cancer. Radiol Clin North Am. 2000;38: 59-85.

8. Shinohara K, Wheeler TM, Scardino PT. The appearance of prostate cancer on transrectal ultrasonography: correlation of imaging and pathological examinations. J Urol. 1989;142:76-82.

9. Purohit RS, Shinohara K, Meng MV, Carroll PR. Imaging clinically localized prostate cancer. Urol Clin North Am. 2003;30:279-293.

10. Shvarts O, Han K, Seltzer M, Pantuck AJ, Belldegrun AS. Positron emission tomography in urologic oncology. Cancer Control. 2002;9:335-342.

11. Jana S, Blaufox MD. Nuclear medicine studies of the prostate, testes, and bladder. Semin Nucl Med. 2006;36:51-72.

12. Albrecht S, Bucheggar F, Soloviev D, et al. ${ }^{11} \mathrm{C}$-Acetate PET in the early evaluation of prostate cancer recurrence. Eur J Nucl Med Mol Imaging. 2007;34: $185-196$.

13. Bos R, van Der Hoeven JJ, van Der Wall E, et al. Biologic correlates of ${ }^{18}$ fluorodeoxyglucose uptake in human breast cancer measured by positron emission tomography. J Clin Oncol. 2002;20:379-387.

14. Schoder H, Larson SM. Positron emission tomography for prostate, bladder, and renal cancer. Semin Nucl Med. 2004;34:274-292.

15. Peng F, Lu X, Janisse J, Muzik O, Shields AF. PET of human prostate xenografts in mice with increased uptake of ${ }^{64} \mathrm{CuCl}_{2}$. J Nucl Med. 2006;47:16491652.

16. Reubi JC. Neuropeptide receptors in health and disease: the molecular basis for in vivo imaging. J Nucl Med. 1995;36:1825-1835.

17. Reubi JC. Regulatory peptide receptors as molecular targets for cancer diagnosis and therapy. Q J Nucl Med. 1997;41:63-70.

18. Reubi JC, Läderach U, Waser B, Gebbers JO, Robberecht P, Laissue JA. Vasoactive intestinal peptide/pituitary adenylate cyclase activating peptide receptor subtypes in human tumors and their tissues of origin. Cancer Res. 2000; 60:3105-3112.

19. Reubi JC, Waser B, Laderach U, Srinivasan A. Pituitary adenylate cyclase activating polypeptide (PACAP) and PACAP II receptors in human tumors: invitro binding of DTPA-linked PACAP analogues [abstract]. Eur J Nucl Med. 1997;24:1058.

20. Blum AM, Mathew R, Cook GA, Metwali A, Felman R, Weinstock JV. Murine mucosal T cells have VIP receptors functionally distinct from those on intestinal epithelial cells. J Neuroimmunol. 1992;39:101-108.

21. el Battari A, Martin JM, Luis J, et al. Solubilization of the active vasoactive intestinal peptide receptor from human colonic adenocarcinoma cells. J Biol Chem. 1988;263:17685-17689.

22. Couvineau A, Luburthe M. The human vasoactive intestinal peptide receptor: molecule identification by covalent cross-linking in colonic epithelium. J Clin Endocrinol Metab. 1985;61:50-55.

23. Zia H, Hida $\mathrm{T}$, Jakowlew $\mathrm{S}$, et al. Breast cancer growth is inhibited by VIP hybrid, a synthetic VIP receptor antagonist. Cancer Res. 1996;56:34863489.

24. Zia H, Leyton J, Loecho T, Moody TW. PACAP receptors are present on breast cancer cell lines [abstract]. Proc Am Assoc Cancer Res. 1997;38:117.

25. Said SI, Mutt V. Polypeptide with broad biological activity: isolation from small intestine. Science. 1970;169:1217-1218.

26. Bolin DR, Cottrell J, Garippa R, et al. Composition of cyclic and linear analogs of vasoactive intestinal peptide. Drug Des Discov. 1996;13:107-114.

27. Thakur ML, Aruva MR, Gariepy J, et al. PET imaging of oncogene overexpression using ${ }^{64} \mathrm{Cu}$-vasoactive intestinal peptide (VIP) analog: comparison with ${ }^{99 m}$ Tc-VIP analog. J Nucl Med. 2004;45:1381-1389.

28. Chakder S, Rattan S. The entire vasoactive intestinal polypeptide molecule is required for the activation of the vasoactive intestinal polypeptide receptor: functional and binding studies. J Pharmacol Exp Ther. 1993;266:392-399.

29. Pallela VR, Thakur ML, Chakder S, Rattan S. Tc- $99 \mathrm{~m}$ labeled vasoactive intestinal peptide receptor agonist: functional studies. J Nucl Med. 1999;40: 352-360.

30. Thakur ML, Aruva M, Bolewska-Pedyczak E, Gariepy J. Preparation of Cu-64 and Tc-99m- $\mathrm{N}_{2} \mathrm{~S}_{2}$-vasoactive intestinal peptide (VIP) for imaging gene expression [abstract]. J Labelled Comp Radiopharm. 2003;46(suppl):S128. 
31. The GraphPad guide to analyzing radioligand binding data [GraphPad Software Web site]. Available at: http://www.graphpad.com/curvefit/scatchard_plots.htm. Accessed November 6, 2007.

32. Receptor binding assays. In: assay guidance manual, version 4.1 [NIH Chemical Genomics Center Web site]. Available at: http://www.ncgc.nih.gov/guidance/ section5.html\#saturation-binding. Accessed November 6, 2007.

33. Obata A, Yoshimoto M, Kasamatsu S, et al. Intra-tumoral distribution of ${ }^{64} \mathrm{Cu}-$ ATSM: a comparison study with FDG. Nucl Med Biol. 2003;30:529-534.

34. Zhang K, Aruva MR, Shanthly N, et al. Vasoactive intestinal peptide (VIP) and pituitary adenylate cyclase activating peptide (PACAP) receptor specific peptide analogues for PET imaging of breast cancer: in vitro/in vivo evaluation. Regul Pept. July 6, 2007 [Epub ahead of print].

35. Bass LA, Wang M, Welch MJ, Anderson CJ. In vivo transchelation of copper-64 from TETA-octreotide to superoxide dismutase in rat liver. Bioconjug Chem. 2000;11:527-532.
36. Jones-Wilson TM, Deal KA, Anderson CJ, et al. The in vivo behavior of copper-64-labeled azamacrocyclic complexes. Nucl Med Biol. 1998;25: 523-530.

37. Tian X, Aruva MR, Zhang K, et al. PET imaging of CCNDl mRNA in human MCF7 estrogen receptor-positive breast cancer xenografts with oncogenespecific $\left[{ }^{64} \mathrm{Cu}\right]$ chelator-peptide nucleic acid-IGF1 analog radiohybridization probes. J Nucl Med. 2007;48:1699-1707.

38. Klomp AE, Tops BB, Van Denberg IE, Berger R, Klomp LW. Biochemical characterization and subcellular localization of human copper transporter 1 (hCTR1). Biochem J. 2002;364:497-505.

39. Eisses JF, Chi Y, Kaplan JH. Stable plasma membrane levels of hCTR1 mediate cellular copper uptake. J Biol Chem. 2005;280:9635-9639.

40. Thakur ML, Marcus CS, Saeed S, et al. ${ }^{99 \mathrm{~m} T c-l a b e l e d ~ v a s o a c t i v e ~ i n t e s t i n a l ~}$ peptide analogue for rapid localization of tumors in humans. J Nucl Med. 2000; 41:107-110. 